\title{
CONFLICT RESOLVING MODEL KASI PEMERINTAHAN KELURAHAN KADEMANGAN (Studi pada optimalisasi penanganan dokumen kependudukan penduduk rentan di Kelurahan Kademangan)
}

\author{
Bambang Septiawan \\ Fakultas Ekonomi Universitas Islam Balitar Blitar \\ emal:okbamz@gmail.com
}

\section{Kata Kunci:}

konflik, organisasi, model pemecahan konflik, manajemen sumber daya manusia

\section{Keywords: \\ conflict, organization, conflict resolving model, human resource management}

\begin{tabular}{l}
\hline Bambang Septiawan CONFLICT \\
RESOLVING MODEL KASI \\
PEMERINTAHAN \\
KELURAHAN KADEMANGAN \\
(Studi pada optimalisasi \\
penanganan dokumen \\
kependudukan penduduk rentan \\
di Kelurahan Kademangan) \\
(2019). Akuntabilitas: Jurnal \\
Ilmu-Ilmu Ekonomi, 12(1), 41-58. \\
https://doi.org/10.35457/akunta \\
bilitas.v12i1.720
\end{tabular}

\begin{tabular}{l}
\hline ABSTRAK \\
\hline Penelitian ini berfokus untuk menginvestigasi bagaimana cara Kasi \\
Pemerintahan Kelurahan Kademangan dalam mengatasi konflik yang \\
terjadi yaitu masalah dokumen kependudukan penduduk rentan. \\
Penelitian ini termasuk kualitatif dan menitik beratkan pada \\
fenomenologi. Data diambil dengan cara wawancara tidak terstruktur \\
dan studi literature. Hasil penelitian ini menunjukan conflict resolving \\
problem meluputi identifikasi masalah, konsultasi, pertemuan dan \\
pembentukan tim, sosialisasi Ketua RT, pengambilan data, pemrosesan \\
data, pembagian dokumen kependudukan, dan monitoring serta \\
evaluasi.
\end{tabular}

ABSTRACT

This research is focused to investigate the way of Vice Village Chief of Kademangan district which has responsibility in governmental affair to resolve conflict about the citizenship documentation of susceptible citizen. This research uses qualitative approach and concerns to fenomenologi area. The data is taken from unstructured interview and literature studies. The result show that conflict resolving model includes problem identification, consultation, meeting and constructing team, sosialiszation to the chief of neighborhood association, taking the data, processing data, separating the document, and evaluation as well as monitoring.

Key words:

\section{PENDAHULUAN}

Sebuah organisasi pasti mencanangkan visi dan misi tertentu dalam rangka mewujudkan tujuan utamanya. Seiring berjalannya waktu, dalam kehidupan berorganisasi tidaklah selalu berjalan lancar dalam pelaksanaan pola Conflict Resolving Model Kasi Pemerintahan Kelurahan Kademangan (Studi pada Optimalisasi penanganan dokumen kependudukan penduduk rentan di Kelurahan Kademangan) 
keorganisasiannya. Organisasi tentunya menemui banyak kendala atau yang biasa disebut dengan konflik. Konflik merupakan tantangan dan masalah yang muncul ditengah perjalanan organisasi pada saat mewujudkan tujuan-tujuannya. Menurut Pilii (2016) konflik dalam organisasi bisa dedefinisikan sebagai ketidak samaan pendapat antar satu atau dua individu bahkan lebih dalam grup atau diluar grup yang berakibat pada satu pekerjaan yang harus dilakukan secara bersamaan. Sejatinya, konflik harus segera diselesaikan dengan berbagai macam metode dan jalan keluar, karena jika dibiarkan berlarut-larut akan mengakibatkan stress dan menurunkan kinerja organisasi. Septiawan (2018) menjelaskan jika stres sering kali mengakibatkan pekerjaan terganggu mulai dari perorangan dan merambah pada keseluruhan organisasi.

Oleh karena itu, langkah konkret yang progresif harus segera dilakukan untuk mengatasi konflik agar tidak berdampak stres dan mampu menurunkan kinerja perorangan bahkan organisasi. Tjahjono (2016) Mendeskripsikan jika konflik bisa dikelola dengan metode kerjasama dan metode kompetisi. Kerjasama bisa diwujudkan dengan cara kolaborasi dan kompromi seperti melakukan rapat koordinasi dan mencari kesepakatan atas konflik yang terjadi. Sedangkan kompetisi bisa diwujudkan dengan cara adu kreatifitas atas individu atau organisasi sehingga nantinya akan muncul solusi terbaik dari konflik yang muncul tersebut.

Organisasi resmi atau instansi pemerintah juga tidak luput dari konflik. Hal tersebut juga menimpa Kelurahan Kademangan khususnya dibidang pemerintahan. Salah satu konfliknya adalah persoalan administrasi kependudukan penduduk rentan. Penduduk rentan administrasi kependudukan berdasarkan Dinas Kependudukan Kota Semarang (2017) adalah penduduk yang mengalami hambatan dalam memperoleh dokumen kependudukan yang disebabkan oleh bencana alam dan korban bencana sosial. Bencana alam yang dimaksud seperti tanah longsor, banjir, gunung meletus, tsunami dan lain sebagainya. Sedangkan bencana sosial seperti anak terlantar dan orang lanjut usia terlantar, orang gila, dan komunitas terpencil. 
Setiap penduduk wajib melaporkan peristiwa kependudukan mereka, untuk memperoleh dokumen kependudukan. Pelaporan tersebut masuk dalam kategori Pencatatan Sipil, yaitu Pencatatan Peristiwa penting yang dialami oleh seseorang dalam Regester Pencatatan Sipil pada Instansi Pelakasana (UUD No.24 Tahun 2013 Tentang Perubahan Atas UUD No.23 Tahun 2006). Masih banyak penduduk rentan yang dokumen kependudukanya tidak terurus sebagai akibat keadaan fisik non fisik. Terdapat sekitar 0,3\% (24 orang) penduduk rentan administrasi kependudukan di Kelurahan Kademangan. Mayoritas masuk dalam kategori orang terlantar yang tidak terpenuhi sandang pangan serta kategori korban bencana sosial. Kesadaran mereka tentang administrasi kependudukan sangat rendah, sehingga jika ada bantuan yang datang sering kali menghambat mereka untuk memperoleh bantuan karena terkendala masalah tersebut.

Lebih jauh lagi, konflik yang telah muncul tersebut merupakan salah satu urgensi yang harus segera dipecahkan olek Kasi. Pemerintahan Kelurahan Kademangan. Sebagai Aparatur Sipil Negara (ASN), berdasarkan Peraturan Menteri Pendayagunaan Aparatur Negara dan Reformasi Birokrasi Republik Indonesia Nomor 11 Tahun 2015 tentang Road Map Reformasi Birokrasi 2015-2019, beberapa permasalahan strategis yang masih harus diperbaiki melalui pelaksanaan reformasi birokrasi salah satunya adalah pelayanan publik masih belum memiliki kualitas yang diharapkan. Tantangan yang dihadapi terkait dengan permasalahan ini adalah masih rendahnya realisasi kepengurusan dokumen kependudukan penduduk rentan sehingga sangat berpengaruh terhadap program pembangunan Kelurahan Kademangan. Untuk menjawab tantangan tersebut, maka model dari pemecahan konflik yang terjadi (dokumen penduduk rentan) di Kelurahan Kademangan harus ditemukan sebuah formulasi yang tepat agar kinerja ASN tetap kredibel di masyarakat.

Beberapa teori yang berkaitan dengan penelitian ini dapat dijabarkan sebagai berikut:

Konflik merupakan ketidak sesuaian ide atau tindakan baik yang terjadi antar individu, antar kelompok, individu dengan kelompok, atau kelompok dengan 
kelompok untuk tujuan tertentu. Menurut Robbins (2013) konflik adalah sebuah usaha dimana satu pihak sengaja membuat kegiatan negatif yang bertujauan untuk menghalangi pihak lain karena tidak dianggap satu tujuan. Kemudian, Indrawijaya (2010) mejelaskan konflik dalam pengertian yang sangat luas dapat diartikan sebagai segala macam bentuk hubungan antarmanusia yang bersifat berlawanan. Konflik merupakan tindakan kontradiksi yang terjadi dalam organisasi yang bermula dari perbedaan tujuan, ideologi, atau realisasi.

Ada 4 pandangan tentang konflik, Robbins (2013) mendeskripsikan yang pertama adalah pandangan tradidional (the traditional view) yang berasumsi jika semua konflik akan mengakibatakan hal yang buruk dan harus dihindari. Konflik yang terjadi merupakan hasil dari komunikasi yang lemah, rendahnya sikap keterbukaan, dan rendahnya sikap percaya pada orang lain, serta kesalahan pimpinan dalam menanggapi aspirasi dan keluhan karyawan. Kedua, pandangan interaksi (interactionist view) mempercayai jika konflik tidak hanya memberikan hal positif pada organisasi, tetapi juga terkadang memberikan dampak yang efektif untuk kinerja organisasi. Konflik memang tidak bisa dihindari dan seringkali menimbulkan kerugian, namun dibalik itu semua ada banyak hal positif yang bisa dimanfaatkan untuk kemajuan organisasi. Ketiga, konflik fungsional (fuctional conflict) yaitu konflik yang dapat mendukung tujuan organisasi dan meningkatkan kinerja organisasi. Terahir adalah konflik disfungsional (disfuctional conflict) konflik yang merugikan dan menghalangi tujuan organisasi.

\section{Tipe atau Jenis Konflik}

Ada tiga tipe konflik menurut Robbins (2013), yaitu:

a. Konflik Tugas (task conflict) terkait dengan tugas dan tujuan dalam pekerjaan.

b. Konflik Hubungan (relationship conflict) yang berfokus pada hubungan interpesonal.

c. Konflik Proses (Process conflict) terkait dengan bagaimana suatu pekerjaan diselesaikan. 


\section{a. Konflik peran}

Terdapatnya berbagai jenis peranan pada satu posisi yang menyebabkan terjadinya konflik peranan, karena seorang yang menerima pesan peranan yang tidak sesuai.

b. Konflik Antarperanan

Peranan ganda inilah yang menimbulkan terjadinya konflik antar peran, yaitu konflik yang terjadi karena seseorang harus memainkan berbagai macam peranan pada kelompok yang berbeda.

\section{Strategi dalam Mengatasi Konflik}

Menurut Robbins (2013) ada lima langkah dalam mengatasi konflik:

a. Competition digunakan jika ada hal yang mendesak dan perlu dilakukan dalam waktu singkat serta hal tersebut berhubungan dengan kesejahteraan organisasi.

b. Collaboration ketika ada beberapa pendapat yang berbeda mengenai sudut pandang langkah ini dilakukan dan lebih cenderung untuk berbicara dari hati ke hati.

c. Avoidance dilakukan ketika isu yang muncul hanya hal yang remeh, atau jika ada isu yang lebih besar dari isu tersebut, kemudian pihak yang berkonflik bisa menyelesaikan dengan jalan yang lebih efektif.

d. Acommodation dilakukan ketika kita salah, ketika memerlukan alasan untuk diperlajari, dan ketika kita menemukan hal lain yang lebih benar dan positif.

e. Compromise jika pihak yang berselisih rela sama-sama berkorban untuk menyelesaikan konflik yang ada.

Sedangkan Siswanto (2008) berpendapat jika ada 3 cara untuk menghadapi konflik:

a. Menghindari konflik, didasarkan pada kepercayaan jika konflik adalah sesuatu yang buruk dan merugikan. 
b. Menekan konflik, didasarkan atas pandangan bahwa konflik dapat dibatasi. Oleh karena itu, strategi ini menghendaki pihak yang berkonflik untuk menjalin kerjasama dan menekan terjadinya konflik secara berbarengan.

c. Menjadikan konflik sebagai sesuatu yang positif, memandang jika konflik memiliki nilai positif. Konflik dalam organisasi disajikan dalam perpektif positif untuk melakukan inovasi dan perubahan organisasi kearah lebih baik.

\section{Teknik Manajemen Konflik}

Beberapa penjabaran dari teknik manajemen konflik menurut Robbins (2013) adalah:

a. Problem Solving merupakan pertemuan tatap muka dari kubu-kubu yang berkonflik untuk tujuan mengidentifikasi masalah dan menyelesaikannya melalui diskusi terbuka.

b. Super ordinate goals adalah membicarakan tujuan yang tidak tercapai tanpa melibatkan setiap kubu yang berkonflik.

c. Expansion of resources ketika konflik disebabkan oleh kekurangan sumber (uang, promosi, kesempatan, ruang kerja), ekspansi dari sumber bisa diciptakan dengan win-win solution.

d. Avoidance adalah pengambilan kembali atau penindihan dari konflik yang terjadi.

e. Smoothing adalah mengambil peran berbeda sambil menekankan perhatian pada kubu yang berkonflik.

f. Compromise ketika setiap kubu yang berkonflik mengkompromikan ide-ide mereka.

g. Authoritative command adalah manajemen menggunakan otoritas mereka untuk mengatasi konflik dan kemudian mengkomunikasikan keingginannya pada kubu yang terlibat. 
Bambang Septiawan/ Akuntabilitas 12 (1) 2019; 41-58

ISSN 2527-3906 (Online) ISSN 1978-6255 (Print)

h. Altering the human variable merupakan penggunaan teknik perubahan perilaku seperti training atau tindakan perubahan sikap dan kebiasaan dari penyebab konflik.

i. Altering the structural variables merupakan perubahan struktur organisasi formal dan pola interaksi dari kubu yang berkonflik melalui desain ulang pekerjaan, transfer, dan menciptakan koordinasi antar lini.

\section{Hasil Konflik}

Ada tiga hasil konflik, sesuai dengan Sunyoto (2013):

a. Kalah-kalah, menunjukkan salah satu pihak tidak ada yang terpenuhi keinginanya, selain itu bisa jadi masalahnya belum terpecahkan.

b. Menang-kalah, satu pihak diuntungkan dan pihak lain dirugikan. Hal ini biasanya berkaitan dengan kompetisi sehingga yang memiliki kemampuan lebih akan menang.

c. Menang-menang, kedua belah pihak sama-sama diuntungkan dan jalan kerjasama dalam pemecahan masalah sangat berguna dalam kasus ini.

Berdasarkan pandangan yang sudah diuraikan, peneliti memformulasikan rumusan masalah yaitu bagaimana conflict resolving model yang diaplikasikan Kasi Pemerintahan Kelurahan Kademangan? Berdasarkan rumusan masalah tersebut, tujuan penelitian ini menjelaskan conflict resolving model yang diaplikasikan Kasi Pemerintahan Kelurahan Kademangan. Penelitian ini menganalisa tentang langkah konkret yang dilakukan Kasi Pemerintahan Kelurahan Kademangan dalam model penyelsaian konflik dengan masalah yakni dokumen kependudukan penduduk rentan, dan mengelaborasikan dengan teori-teori konflik dari parah ahli untuk memperdalam pembahasan. Selain itu, penelitian ini tidak membahas tentang sistem pelayanan dan administrasi pemerintahan yang dilakukan oleh Kasi Pemerintahan Kelurahan Kademangan secara detail.

Kegunaan dan manfaat penelitian ini adalah pertama, secara teoritis penelitian ini diharapkan mampu memperkaya khasanah keilmuan tentang teori organisasi, konflik organisasi, dan penyelesaian konflik. Penelitian ini bisa jadi bahan rujukan 
khususnya dalam bidang konflik pada ranah teori dan perilaku organisasi. Kedua secara praktis penelitian ini mampu memberikan data aktual untuk para pembaca terutama mereka yang ingin mempelajari konflik dalam organisasi. Kemudian bagi Kelurahan kademangan penelitian ini dapat digunakan sebagai masukan dan pertimbangan dalam pengambilan kebijakan lebih lanjut tentang keefektifan dalam organisasi terutama langkah-langkah dalam penyelesaian konflik.

\section{METODOLOGI PENELITIAN}

Penelitian ini termasuk dalam ranah kualitatif dan berfokus pada metode interview. Kunci dalam metode interview kualitatif adalah hubungan yang natural antara pewawancara dengan yang diwawancarai. Oleh karena itu, penelitian ini berfokus pada wawancara fenomenologi. Menurut Symon (2004) fenomenologi sendiri adalah filosofi tradisional yang memiliki pengaruh fundamental pada keilmuan sosial ekonomi dalam model pengembangan metode penelitian kualitatif. Kunci utama dari metode fenomenologi menitik beratkan pada tempat dan kejadian yang dibutuhkan peneliti untuk menganalisa dugaan atau perkiraannya tentang fenomena yang sedang diinvestigasi.

Subjek atau informan dalam penelitian ini adalah Kasi Pemerintahan Kelurahan Kademangan. Peneliti mengambil subjek tersebut atas dasar, beban kerja Kasi Pemerintahan tergolong yang tertinggi dan terbanyak dibanding dengan kasi yang lainnya. Sehingga hal ini menuntut yang bersangkutan agar menyelesaikan konflik yang terjadi secara efektif dan efisien. Lokasi penelitian ini terletak di Kelurahan Kademngan Kecamatan Kademangan Kabupaten Blitar (Jalan Raya Trisula No.32). Waktu pelaksanaan penelitian ini mulai April 2019 sampai Juli 2019.

Data dalam penlitian ini adalah kata-kata yang diucapkan Kasi Pemerintahan secara lisan dan gesture pada saat wawancara dilaksanakan. Selain itu hasil pengamatan berupa catatan kecil juga digunakan sebagai data pendukung, terutama dokumen pendukung dalam penyelsaian konflik yang diaplikasikan oleh subjek. Instrument utama dalam penelitian ini adalah peneliti sendiri. Adapun instrumen 
pendukung dalam penelitian ini adalah recorder, kamera, dan catatan yang terdapat dalam telepon genggam.

Teknik pengumpulan data dalam penelitian ini diformulasikan dalam beberapa langkah. Pertama, wawancara yang dilakukan secara tidak terstruktur dan spontan. Wawancara tidak terstruktur formulasi dan urutan pertanyaannya dapat lebih luwes sehingga akan mengikuti alur responden. Terkadang juga dilakukan wawancara spontan untuk menggali informasi tambahan penting yang terlewat oleh peneliti. Alat bantu yang digunakan adalah recorder telpon genggam serta catatan. Wawancara dalam penelitian ini dilakukan pada Kasi Pemerintahan Kelurahan Kademangan.

Kedua, studi pustaka dilakukan untuk mencari sumber-sumber tertulis yang bisa digunakan untuk memperkuat analisa data dalam penelitian ini. Literatur yang diambil dalam penelitian ini adalah dokumen-dokumen yang menjadi tugas subjek penelitian saat melaksanakan tugas kerja, baik dari segi individu maupun lembaga.

Teknik analisa dalam penelitian ini ada beberapa tahap. Setelah dilakukan proses wawancara. Peneliti melakukan transkripsi atau proses dari data audio menjadi data tertulis atau transkrip. Lebih dari itu hasil transkrip juga dikombinasikan dengan studi pustaka yang telah dilakukan dan didokumentasikan. Sehingga hasil yang didapatkan jauh lebih terpercaya. Kemudian, dilakukan reduksi data transkrip. Peneliti menghapus bagian-bagian hasil transkrip yang tidak diperlukan dalam proses analisa sehingga transkripsi yang ada mampu dijadikan acuan dalam menjawab rumusan masalah.

Selanjutnya, data disajikan dan dianalisa serta diintepretasikan, sehingga akan muncul sebuah model penyelesaian konflik yang dilakukan oleh subjek penelitian. Kemudian, berdasarkan teori yang telah diuraikan dalam penelitian ini. Model tersebut dielaborasikan dan dikomparasikan. Terakhir, setelah seluruh data dianalisa, dapat ditarik kesimpulan mengenai masalah penelitian. Penarikan kesimpulan merupakan bagian akhir dari hasil penelitian. 


\section{HASIL DAN PEMBAHASAN}

Hasil dan pembahasan dalam penelitian ini dapat dijabarkan sebagai berikut. Berdasarkan hasil analisa yang telah dilakukan oleh peneliti konflik yang terjadi bukanlah konflik tradisional atau konflik yang akan menimbulkan kerugian bagi organisasi, menurut Robbins (2013) lebih mengarah pada interactionist view. Hal tersebut terjadi karena keberadaan konflik itu sendiri membawa hal positif untuk kinerja subjek dan stafnya. Lebih dari itu, fuctional conflict juga terindikasi terjadi dalam hal ini, karena konflik yang terjadi mampu mendorong subjek dan stafnya untuk lebih kreatif dan inovatif sehingga tujuan organisasinya dapat tercapai yaitu memberikan layanan yang baik, cepat, dan mudah bagi masyarakat Kelurahan Kademngan khususnya penduduk rentan yang terkendala dokumen kependudukannya.

Walaupun demikian konflik disini bukan termasuk dalam kategori konflik peran dan konflik antar peran. Konflik peran merupakan tugas atau kewajiban yang harus dihadapi oleh seseorang dalam satu kesempatan kerja dengan tingkat kemampuan diluar keahliannya, sedangkan konflik antar peran adalah adanya multi tugas berbeda dan itu harus dilaksanakan dalam kelompok atau organisasi yang berbeda pula dalam satu waktu, berdasarkan Sunyoto (2013). Selanjutnya, konflik ini juga tidak tergolong dalam disfuctional conflict yaitu konflik yang mampu menjadi penghalang organisasi untuk mencapai tujuannya berdasarkan Robbins (2013). Sehingga, konflik yang dialami Kasi Pemerintahan Kelurahan Kademangan sebetulnya adalah konflik yang positif dan mampu untuk mengangkat kinerja dan mencapai tujuan organisasi jika dikerjakan dengan tepat, cepat, akurat, dan inovatif.

Lebih dari itu, konflik ini masih tergolong dalam 3 tipe. Robbins (2013) menjabarkan tipe tersebut adalah konflik tugas, konflik hubungan, dan konflik proses. Pertama, konflik tugas yang dialami oleh Kasi Pemerintahan Kelurahan Kademangan salah satunya adalah pemenuhan urusan pelayanan kependudukan. Fakta tersebut juga sejalan dengan visi misi organisasi Kelurahan Kademangan secara keseluruhan untuk menciptakan kulaitas layanan yang prima. Kedua, konflik hubungan dalam ini adalah hubungan interpersonal antara Kasi Pemerintahan 
Kelurahan Kademangan dengan penduduk rentan yang terkendala proses dokumen kependudukannya. Terakhir, konflik proses mencakup metode atau cara yang digunakan Kasi Pemerintahan Kelurahan Kademangan dalam penyelesaian masalah dokumen kependudukan penduduk rentan.

Selanjutnya berdasarkan hasil wawancara dan studi pustaka yang telah dilakukan peneliti, berikut tabel dan diagram alir formulasi conflict resolving model yang diaplikasikan oleh Kasi Pemerintahan Kelurahan Kademangan.

Tabel Conflict Resolving Model

\begin{tabular}{|c|c|c|c|c|}
\hline NO & KEGIATAN & DESKRIPSI & OUTPUT & $\begin{array}{l}\text { TARGET } \\
\text { KINERJA }\end{array}$ \\
\hline 1 & $\begin{array}{l}\text { Konsultasi dengan } \\
\text { atasan }\end{array}$ & $\begin{array}{l}\text { Melakukan } \\
\text { konsultasi dengan } \\
\text { Kepala Kelurahan } \\
\text { Kademangan dan } \\
\text { Sekretaris Kecamatan } \\
\text { Kademangan untuk } \\
\text { memformulasikan } \\
\text { terobosan. }\end{array}$ & $\begin{array}{l}\text { Terwujudnya } \\
\text { rencana model } \\
\text { penyelesaian konflik } \\
\text { yang sudah } \\
\text { disempurnakan }\end{array}$ & $\begin{array}{c}\text { Terbentuk } \\
\text { konsep baku } \\
\text { dalam } \\
\text { penyelesaian } \\
\text { konflik }\end{array}$ \\
\hline 2 & $\begin{array}{l}\text { Rapat } \\
\text { pembentukan Tim } \\
\text { dokumen } \\
\text { kependudukan } \\
\text { (dokduk) } \\
\text { Penduduk Rentan }\end{array}$ & $\begin{array}{l}\text { Tim dokumen } \\
\text { kependudukan } \\
\text { penduduk rentan } \\
\text { yang dibentuk } \\
\text { melalui SK yang } \\
\text { ditandatangani oleh } \\
\text { Kepala Kelurahan } \\
\text { Kademangan }\end{array}$ & $\begin{array}{l}\text { Penyamaan persepsi } \\
\text { dan terbentuknya } \\
\text { tim }\end{array}$ & 1 buah SK \\
\hline 3 & $\begin{array}{l}\text { Sosialisasi } \\
\text { Pelayanan } \\
\text { Dokumen }\end{array}$ & $\begin{array}{l}\text { Sosialisasi ditujukan } \\
\text { untuk ketua RT } \\
\text { dilingkungan }\end{array}$ & $\begin{array}{l}\text { Warga memahami } \\
\text { tentang adminduk } \\
\text { renta dokumen }\end{array}$ & 30 orang \\
\hline
\end{tabular}

Efektifitas Promosi Dalam Peningkatan Penjualan Produk Kosmetik di Kota Blitar https:// doi.org/10.35457/akuntabilitas.v12i1.720

(C) 2019 Akuntabilitas: Jurnal Ilmu-Ilmu Ekonomi. Semua hak cipta dilindungi undang-undang 


\begin{tabular}{|c|c|c|c|c|}
\hline & $\begin{array}{l}\text { Kependudukan } \\
\text { bagi Penduduk } \\
\text { Rentan Kepada } \\
\text { Kepala RT }\end{array}$ & $\begin{array}{l}\text { Kelurahan } \\
\text { Kademangan }\end{array}$ & $\begin{array}{l}\text { kependudukan } \\
\text { penduduk rentan }\end{array}$ & \\
\hline 4 & $\begin{array}{l}\text { Melaksanakan } \\
\text { Pendataan } \\
\text { Penduduk Rentan } \\
\text { a. sosialisasi } \\
\text { kepada seluruh } \\
\text { RT; } \\
\text { b. menbagikan } \\
\text { formulir isian } \\
\text { biodata penduduk } \\
\text { WNI rentan; } \\
\text { c. pendampingan } \\
\text { saat pendataan. }\end{array}$ & $\begin{array}{l}\text { Tim mendata } \\
\text { penduduk rentan } \\
\text { dan menganalisa } \\
\text { adminduk kebutuhan } \\
\text { meraka }\end{array}$ & $\begin{array}{l}\text { Semua penduduk } \\
\text { rentan telah terdata }\end{array}$ & $100 \%$ terdata \\
\hline 5 & $\begin{array}{l}\text { Memproses } \\
\text { dokumen } \\
\text { kependudukan } \\
\text { a. menginput data } \\
\text { b. } \\
\text { verifikasi/validasi } \\
\text { c. mencetak }\end{array}$ & $\begin{array}{l}\text { Melakukan } \\
\text { koordinasi dan } \\
\text { proses } \\
\text { pendampingan } \\
\text { administrasi } \\
\text { penduduk rentan } \\
\text { dengan } \\
\text { Dispendukcapil } \\
\text { Kabupaten Blitar. }\end{array}$ & $\begin{array}{l}\text { Tercetak adminduk } \\
\text { bagi penduduk } \\
\text { rentan }\end{array}$ & $100 \%$ terdata \\
\hline 6 & $\begin{array}{l}\text { Pembagian } \\
\text { dokumen } \\
\text { kependudukan }\end{array}$ & $\begin{array}{l}\text { Semua penduduk } \\
\text { rentan telah } \\
\text { mendapatkan hak } \\
\text { atas dokumen } \\
\text { kependudukan } \\
\text { mereka }\end{array}$ & $\begin{array}{l}\text { Penduduk rentan } \\
\text { memiliki dokumen } \\
\text { kependudukan } \\
\text { mereka }\end{array}$ & $100 \%$ terbagi \\
\hline
\end{tabular}


ISSN 2527-3906 (Online) ISSN 1978-6255 (Print)

\begin{tabular}{|c|l|l|l|c|}
\hline Bambang Septiawan/ Akuntabilitas 12 (1) 2019; 41-58 & ISSN 1978-6255 (Print) \\
\hline $\mathbf{7}$ & Mentoring dan & Melakukan rapat & & Perbaikan \\
& evaluasi & koordinasi dengan & & kualitas \\
& pelayanan & tim untuk & & \\
kepumen & memperbaiki sistem \\
bagi penduduk & Kinerja lebih baik & \\
rentan & & & \\
\hline
\end{tabular}

Sumber: Data diolah 2019

\section{Diagram Alir Conflict Resolving Model}

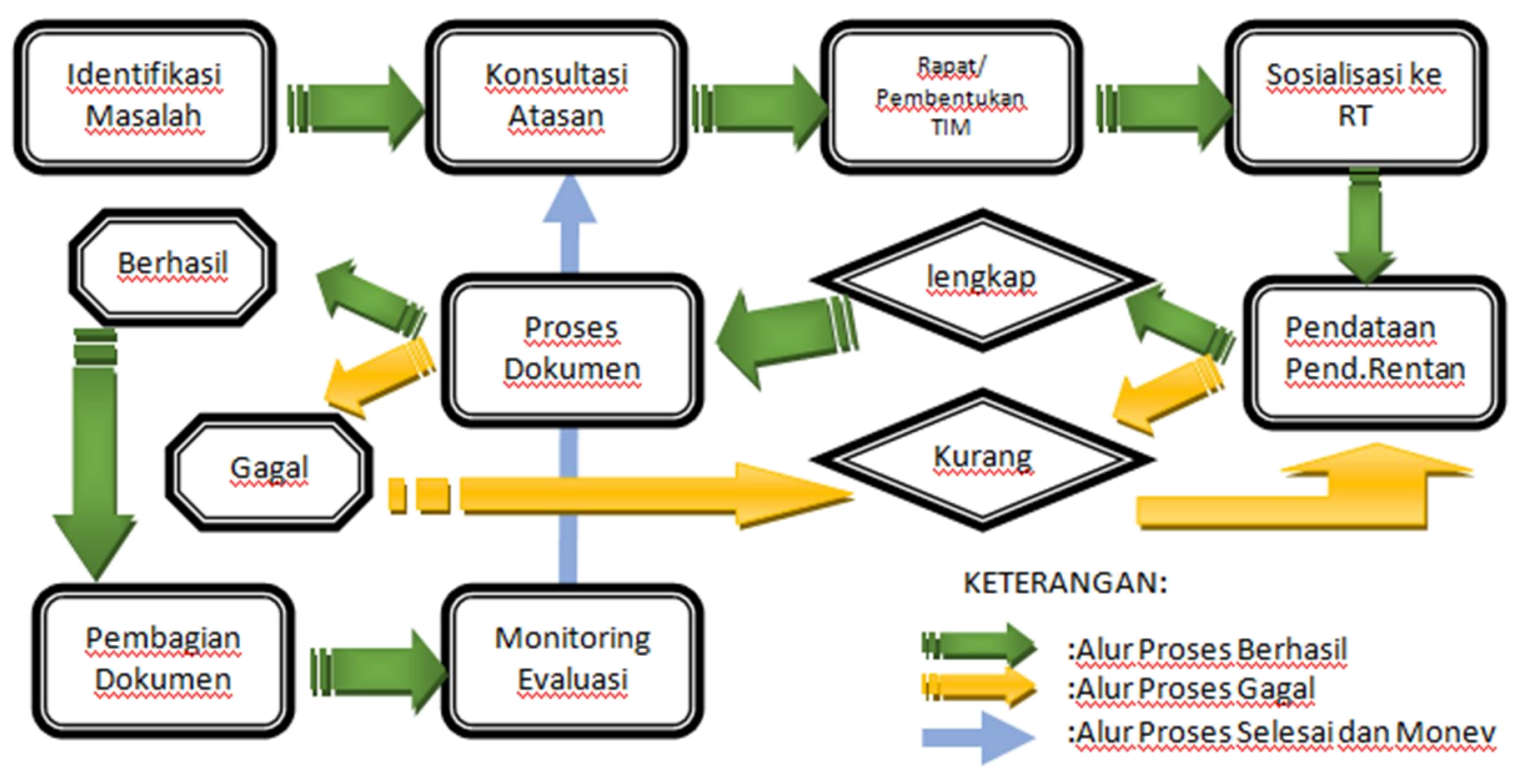

Sumber: Data diolah 2019

Elaborasi teori dan temuan dilapangan dapat dijabarkan dalam beberapa tahap berdasarkan model yang telah diwujudkan dengan tabel maupun diagram tersebut. Pertama, identifikasi masalah yang telah dilakukan merupakan sebuah langkah awal yang dilakukan subjek dalam mengatasi konflik yang terjadi, agar segera terformulasikan model penyelesaian konflik yang cepat dan tepat. Siswanto (2008) menjelaskan jika konflik juga bisa dipandang sebagai hal yang menguntungkan, karena mampu meningkatkan kinerja organisasi dan memunculkan ide kreatif untuk menyelesaikan konflik yang terjadi. Konflik yang terjadi disini sebetulnya melibatkan kubu antara pemerintah dan masyarakat. 
mengakomodir kemauan rakyat yakni penyelesaian dokumen penduduk rentan.

Kemudian, konflik disini juga bertentangan dengan beberapa ahli. Seperti pendapat Robbins (2013) yang menjabarkan dalam salah satu teori avoidance atau menghindari konflik karena dianggap kecil dan remeh. Siswanto (2008) dalam teorinya yang lain juga mengatakan jika konflik bisa diatasi dengan menekannya, yakni memaksa kubu tertentu untuk menyelesaikannya. Hal ini tidak mungkin terjadi dalam kasus ini karena penduduk rentan sejatinya wajib difasilitasi dan sulit untuk menyelesaikannya sendiri, sehingga dua pendapat tersebut tidak sejalan dengan konflik ini.

Kedua, langkah yang dilakukan subjek yaitu melakukan konsultasi dengan atasannya (Kepala Kelurahan Kademangan dan Sekretaris Kecamatan Kademangan). Dua orang tersebut dipilih karena memiliki pengalaman lebih banyak dan lebih menguasai lapangan lebih dahulu daripada subjek. Harapannya, dari hasil konsultasi tercipta formulasi yang lebih efektif untuk mengatasi konflik tentang dokumen penduduk rentan. Langkah ini sesuai dengan pendapat Robbins (2013) yang mengatakan jika collaboration merupakan upaya penyatuan ide-ide yang berbeda sehingga akan ada satu terobosan penyelesaian konflik yang lebih efektif. Selanjutnya, acommodation yakni menyadari kesalahan dan rela melakukan pembelajaran untuk menemukan hal yang lebih benar dan positif. Sebagai pelayan masyarakat, subjek menyadari kekurangannya dalam hal penanganan dokumen kependudukan penduduk rentan. Oleh karena itu yang bersangkutan mencari jalan keluar agar tugasnya dapat dilaksanakan dengan baik dan masyarakat khususnya penduduk rentan sangat terbantu dalam hal dokumen kependudukanya yang belum selesai terurus.

Ketiga, hasil konsultasi dan diskusi dari atasan adalah formulasi dan kebijakan untuk mengatasi masalah tentang dokumen penduduk rentan. Langkah awal yakni melakukan rapat dengan pegawai kelurahan yang lain untuk menginformasikan program dan membentuk tim khusus yang menangani dokumen kependudukan penduduk rentan. Robbins (2013) mengatakan membicarakan tujuan 
Bambang Septiawan/ Akuntabilitas 12 (1) 2019; 41-58

onflik disebut super

ordinate goals. Sengaja rapat internal dilakukan dan tim dibentuk untuk mengefektifkan kinerja organisasi dan menyediakan konsep dan praktik pelayanan yang memuaskan bagi masyarakat. Selanjutnya, langkah ini termasuk altering the structural variables menurut Robbins (2013) karena ada perubahan struktur organisasi formal dan pola interaksi dari kubu yang berkonflik melalui desain ulang pekerjaan, transfer, dan menciptakan koordinasi antar lini. Tim khusus yang dibentuk bertugas khusus untuk memfasilitasi keperluan dokumen penduduk rentan. Disisilain, tahap ini bukan termasuk dalam teori Robbins yang lain (2013) yaitu Expansion of resources, karena konflik tersebut tidak disebabkan oleh kekurangan sumber (uang, promosi, kesempatan, ruang kerja). Konflik ini lebih cenderung mengarah pada kebijakan sistem untuk mempermudah proses pelayanan.

Keempat, sosialiasi konsep dan kebijakan dokumen penduduk rentan kepada ketua RT. Hal ini dilakukan untuk memberikan pemahaman dan sebagai langkah awal untuk mengatasi dokumen penduduk rentan di Kelurahan Kademangan. Berdasarkan Robbins (2013) hal ini termasuk authoritative command. Kelurahan Kademangan menggunakan otoritas mereka untuk mengatasi konflik, selanjutnya mengkomunikasikan kebijakan yang telah dibuat untuk diterapkan. Kebijakan tersebut dibuat secara internal karena proses dan alurnya juga melibatkan pihak lain yaitu Dinas Kependudukan dan Catatan Sipil Kabupaten Blitar yang secara detail diketahui internal saja. Kemudian, pada dasarnya penduduk rentan secara kepengurusan mengalami kesulitan dari sisi proses pengajuan dokumen, maka dari itu tim yang telah dibentuk diharapkan mampu memfasilitasi mereka dari awal hingga akhir.

Kelima, sosialisasi yang dilakukan kepada ketua RT diharapkan mampu memberikan informasi kepada tiap penduduknya terutama yang rentan agar memahami tentang kebijkan dan konsep baru yang telah dijelaskan Kasi Pemerintahan sebagai wakil Kelurahan Kademangan. Selanjutnya, pendataan dilaksanakan untuk mendapatkan data-data yang akurat dan dibutuhkan untuk pengurusan dokumen kependudukan penduduk rentan. Pendataan, dilakukan tim 
yang telah dibentuk untuk mempermudah pengurusan bagi mereka. Sebelumnya, mereka harus kerepotan mengurus sendiri namun sekarang sudah ada tim khusus yang membantu mereka. Robbins (2013) menjelaskan fakta itu sebagai altering the human variable. Teori tersebut menekankan pada penggunaan teknik perubahan perilaku seperti training atau tindakan perubahan untuk merubah sikap dan kebiasaan dari penyebab konflik. Penduduk rentan diharapkan segera menghubungi tim khusus agar membantu proses kepengurusan dokumenya. Sehingga, jika mereka butuh dokumen kependudukan terutama untuk bantuan sosial, mereka akan mudah mendapatkanya dan mengaksesnya.

Keenam, setelah data yang dikumpulkan dan dinyatakan lengkap. Proses dokumen dilakukan tim dan pendampingan pada penduduk rentan saat di Dinas Kependudukan dan Catatan Sipil Kabupaten Blitar. Pendampingan dibutuhkan jika mereka melakukan foto atau proses perekaman lain yang mengharuskan yang bersangkutan datang langsung. Jika data ditolak, timpun juga akan terus membantu untuk menyelesaikanya hingga dokumen kependudukanya selesai. Ketujuh, jika dokumenya telah rampung maka akan langsung dibagikan atau diberikan kepada yang bersangkutan karena pada dasarnya kelengkapan dokumen adalah hak untuk mereka.

Terakhir, monitoring dan evaluasi dilakukan untuk terus memperbaiki sistem dan konsep yang telah terbentuk dan dilaksanakan Kasi.Pemerintahan Kelurahan Kademangan dan timnya. Segala macam kekurangan yang ada dilapangan akan dikaji ulang baik secara peraturan maupun aplikasinya secara nyata. Monitoring dan evaluasi dilaksanakan dengan cara mengkaji seluruh proses dari awal hingga akhir, bersama tim yang terjun dilapangan dan mendengarkan pendapat dari perwakilan warga (Ketua RT). Selanjunya, konsultasi ulang akan dilakukan agar terbentuk sistem yang lebih baik dan memudahkan masyarakat khususnya penduduk rentan untuk kepengurusan dokumen kependudukanya. Win-win solution merupakan hasil akhir dari konflik ini, karena masyarakat khususnya penduduk rentan terbantu dokumen kependudukanya dan pemerintah dalam hal ini Kelurahan kademangan lebih inovatif dalam menciptakan model jika ada konflik yang melibatkan organisasi mereka. 


\section{KESIMPULAN DAN SARAN}

Kesimpulan dari penelitian adalah conflict resolving model yang dilakukan Kasi Pemerintahan Kelurahan Kademangan dalam hal penanganan dokumen kependudukan penduduk rentan meliputi identifikasi masalah, konsultasi, rapat/pembentukan tim, pendataan, pemrosesan data, pembagian dokumen kependudukan, monitoring dan evaluasi.

Saran dari penelitian ini dapat diformulasikan sebagai berikut:

a. Pemerintah Kelurahan Kademangan khususnya Kasi pemerintahan bisa membuat metode atau aplikasi sederhana untuk memfasilitasi masalah dokumen kependudukan. Contohnya, membuat hotline dengan mencantumkan nomor telepon jika ada keluhan atau saran, dan membuat web sederhana untuk pemberian informasi agar warga mudah mengakses.

b. Warga masyarakat (khusunya ketua RT) diharapkan agar pro aktif melapor ke kelurahan jika ada penduduknya terutama penduduk rentan yang belum terpenuhi kebutuhan dokumen kependudukannya maupun administrasi yang lain.

c. Bagi peneliti berikutnya disarankan agar memperdalam penelitian dalam hal komunikasi organisasi dan kualitas pelayanan yang dilakukan di Kelurahan Kademangan Kecamatan Kademangan Kabupaten Blitar.

\section{DAFTAR PUSTAKA}

Dispendukcapil Semarang. (2017). Penduduk Rentan. Melalui: www.dispendukcapil.semarangkota.go.id/berita-PENDUDUK-RENTANDIBERIKAN-NIK-DI-KOTA-SEMARANG. Diakses 7 Juli 2019

Indrawijaya, A.I. 2010. Teori,Perilaku, dan Budaya Organisasi. Bandung: PT Refika Aditama 
Peraturan Menteri Pendayagunaan Aparatur Negara dan Reformasi Birokrasi Republik Indonesia Nomor 11 Tahun 2015 tentang Road Map Reformasi Birokrasi 2015-2019

Pilii,T. et al. (2016). MANAGING CONFLICT IN ORGANISATIONAL CHANGE. International Journal of Agile System and Management, 9 (2), 114-134.

Robbins, S. P. \& Judge, T. A. 2013. Organizational Behaviour. New Jersey: Pearson Education.

Septiawan, Bambang. (2018). ANALISA FAKTOR PENYEBAB STRESS DAN MANAJEMEN STRESS PADA KEPALA SMA BAHRUL MAGHFIROH MALANG. Jurnal al Hikmah, 6 (1), 36-45.

Siswanto \& Sucipto A. 2008. Teori dan Perilaku Organisasi Sebuah Tinjauan Integratif. Malang: UIN Maliki Press

Sunyoto, D. 2013. Teori,Kusioner, dan Proses Analisis Data Perilaku Organisasional. Yogyakarta: CAPS.

Symon, Gillian and Cassell C. 2004. Essential Guide to Qualitative Method in Organizational Research. London: Sage.

Tjahjono, Heru, K. dan Assery Syeh. (2016). MANAJEMEN KONFLIK ANTAR ORGANISASI (STUDI KASUS PERUSAHAAN TELEKOMUNIKASI). Semnas fekon 2016, 130-139.

UUD No.24 Tahun 2013 Tentang Perubahan Atas UUD No.23 Tahun 2006 tentang Pencatatan Sipil 